\title{
Pengaruh Kondisi Fisik Sumur dan Penurunan Kualitas Air (BOD) terhadap Kejadian Penyakit (Studi Kasus Industri Soun di Desa Manjung Kecamatan Ngawen Kabupaten Klaten)
}

\author{
Hera Rachmawati ${ }^{1}$, Mursid Raharjo ${ }^{2}$, Hanan Lanang ${ }^{2}$ \\ ${ }^{1}$ Mahasiswa BagianKesehatan Lingkungan, Fakultas Kesehatan Masyarakat, Universitas Diponegoro \\ ${ }^{2}$ Dosen BagianKesehatan Lingkungan, Fakultas Kesehatan Masyarakat, Universitas Diponegoro
}

Info Artikel : Diterima 25 Januari 2019 ; Disetujui 13 Maret 2019 ; Publikasi 29 April 2019

\begin{abstract}
ABSTRAK
Latar Belakang: Desa Manjung adalah sentral industri soun di Kabupaten Klaten. Industri soun menghasilkan limbah cair yang memiliki kadar BOD di atas baku mutu yaitu sebanyak $1.290 \mathrm{mg} / \mathrm{L}$. Tingginya kadar BOD dalam air menandakan tingginya kandungan mikroorganisme. Kelompok coliform, Escherichia coli, Streptococcus, dan Staphylococcus terkandung di dalam BOD dapat menyebabkan terjadinya gangguan pencernaan dan iritasi kulit. Hal tersebut mungkin dapat menyebabkan terjadinya gangguan pencernaan dan iritasi kulit di Desa Manjung. Tujuan penelitian, untuk mengetahui hubungan kondisi fisik sumur dan penurunan kualitas air (BOD) dengan kejadian gangguan kesehatan yang dialami warga Desa Manjung.

Metode: Penelitian observasional analitik dengan pendekatan case control. Sampel sebanyak 38 responden (19 kelompok kasus dan 19 kelompok kontrol) dengan purposive sampling. Analisis data dengan uji Chi-square.

Hasil: Hasil uji laboratorium kadar BOD terdapat 5 sampel air sumur atau sebesar 13,15\% yang memiliki baku mutu air badan air kelas I dari 38 sampel air sumur. Hasil uji hubungan menunjukkan bahwa kondisi dinding sumur $(p$-value $=0,032$; OR $=7,650(1,370-42,713))$, kondisi lantai sumur $(p$-value $=0,040$; OR $=5,926(1,287$ $27,283)$ ), dan kadar BOD dalam sampel air sumur $(p$-value $=0,046)$ berhubungan dengan kejadian penyakit. Kondisi bibir sumur ( $p$-value $=0,065 ; \mathrm{OR}=6,182(1,101-34,700)$ ) tidak berhubungan dengan kejadian penyakit. Simpulan: Kesimpulan dari penelitian ini adalah gangguan kesehatan yang terjadi berhubungan dengan kondisi dinding sumur, kondisi lantai sumur, dan kadar BOD dalam sampel air sumur.
\end{abstract}

Kata kunci: Air tanah, BOD, industri soun, gangguan pencernaan dan iritasi kulit.

\section{ABSTRACT}

Title:Physical Condition of Wells and Water Quality Degradation (BOD) with the Incidence of Disease (Case study Manjung Village, Ngawen, Klaten District)

Background:Manjung Village is the center of the soun industry in Klaten Regency. The soun industry produces waste water which has a BOD level above the quality standard, which is 1,290 $\mathrm{mg} / \mathrm{L}$. The high level of BOD in water indicates that the content of microorganisms in water is high. Microorganisms such as coliform groups, Escherichia coli, Streptococcus, and Staphylococcus are contained in BOD and can cause digestive and skin irritation. It may cause digestion problem and skin irritation in the Manjung Village. The purpose of this study was to determine the association physical well condition and water quality degradation with health problem experienced by the residents of Manjung Village.

Method:This research is an observational analytic study with a case-control design. The sample in this study are 38 respondents consist of 19 case group and 19 control groups taken based on purposive sampling. Data analysis using Chi-square test.

Result:Laboratory test results of BOD levels contained 5 samples of well water that exceeded the water quality standards of class I water bodies from 38 samples of well water. The results show that the condition of the well wall $(p$-value $=0.032 ;$ OR $=7.650(1,370-42,713))$, the condition of well floor $(p$-value $=0.040 ;$ OR $=5.926$ $(1,287-27,283))$, and BOD levels in well water samples ( $p$-value $=0.046)$ associated with the incidence of disease. Lip well condition ( $p$-value $=0.065 ; O R=6.182(1,101-34,700)$ ) unrelated to disease incidence.

Conclusion: In conclusion, this study show health problems that occur are related to the condition of the well wall, the condition of the well floor, and BOD levels in well water samples. 


\section{PENDAHULUAN}

Desa Manjung merupakan sentral industri soun di Kabupaten Klaten. Saat ini sudah terdapat 55 industri soun yang berada di desa tersebut. Kegiatan produksi soun menghasilkan limbah padat dan limbah cair. Dalam proses produksi, air digunakan dalam berbagai macam kegiatan seperti pencucian bahan baku, pendinginan, media untuk proses pengolahan, penguapan bahan olahan, maupun penunjang kegiatan sanitasi di dalam rumah produksi. ${ }^{1}$

Kegiatan pemukiman dan perindustrian merupakan dua komponen utama yang menyebabkan penurunan kualitas air sehingga mempengaruhi sistem sanitasi lingkungan yang ada di Desa Manjung dan dapat menyebabkan munculnya wabah penyakit yang sumber vektornya berasal dari air (water borne disease).Hal ini diakibatkan karena limbah cair domestik dan industri yang meningkatkan masuknya unsur hara (nutrient) yang berlebihan seperti nitrogen dan fosfor serta bahan organik lainnya yang menyebabkan rendahnya nilai oksigen terlarut (DO) yang berguna bagi kehidupan ekosistem perairan dan tingginya kadar BOD. Penurunan kualitas air tersebut mengakibatkan dampak berkembangnya wabah penyakit akibat sanitasi yang buruk. ${ }^{2}$

Air tanah yang banyak dimanfaatkan oleh warga Desa Manjung untuk kebutuhan. air bersih dan air minum adalah air sumur gali. Parameterfisik, kimia dan biologi dalam suatu air bersih maupun air minum yang dapat digunakan sebagai indikator penentu adanya cemaran atau tidak dalam air tersebut. ${ }^{3}$ Potensi air tanah memiliki variasi antar tempat satu dengan yang lainnya, sehingga permasalahan yang timbul juga tidak sama, akan tetapi secara umum dikatakan bahwa pada setiap daerah terjadi penurunan cadangan air tanah dan penurunan kualitas air tanah. ${ }^{4}$

Zat organik adalah indikator umum bagi pencemaran. Apabila terdapat zat organik yang dapat dioksidasi besar, maka dapat menunjukkan adanya pencemaran. Air yangbersih (jernih)biasanya mengandung mikroorganisme yang relatif lebih sedikitdibandingkan dengan air yang telah tercemar oleh bahan buangan, tetapi untuk air yang tercemar bahan buangan yang bersifat racun mikroorganismenyajuga relatif sedikit. ${ }^{5}$

Berdasarkan penelitian yang telah dilakukan oleh Andita Yulli Puspita Dewi di Desa Manjung, terdapat dua sampel dari total delapan sampel air tanah seluruhnya dinilai kurang layak untuk dikonsumsi dalam kehidupan sehari-hari sebab kandungan BOD dan COD (Chemical Oxygen Demand) telah melebihi baku mutu yang sudah ditetapkan. Hal tersebut diakibatkan oleh limbah cair dari proses produksi mie soun yang dibuang secara langsung ke lingkungan tanpa melalui proses pengolahan terlebih dahulu, sehingga dapat menurunkan kualitas air dan mengganggu kehidupan organisme di sekitarnya. ${ }^{6}$

Berdasarkan data Puskesmas Ngawen tahun 2018 diketahui warga Desa Manjung Kecamatan Ngawen Kabupaten Klaten mengalami beberapa permasalahan kesehatan yaitu gangguan pencernaan dan iritasi kulit. Berdasarkan data tersebut gangguan pencernaan yaitu diarrhea and gastroenteritis of presumed infectious origin menempati nomor 7 dan iritasi kulit yaitu allergic contact dermatitis, unspecified cause menempati nomor 16 dari 20 besar penyakit di Puskesmas Ngawen tahun 2018. Data di Puskesmas juga menunjukkan terdapat 61 kasus gangguan pencernaan dan 75 kasus iritasi kulit yang terjadi selama tahun $2018 .^{7}$

Berdasarkan kondisi lapangan tersebut penelitian ini bertujuan untuk mengetahui kejadian penyakit yang diakibatkan oleh degradasi kualitas air tanah akibat limbah industri rumah tangga yang terjadi di Desa Manjung Kecamatan Ngawen Kabupaten Klaten.

\section{MATERI DAN METODE}

Penelitian ini adalah penelitian observasion alanalitik dengan rancangan case control (kasus kontrol). Populasi adalah semua penduduk yang berdomisili di Desa Manjung Kecamatan Ngawen Kabupaten Klaten yang sesuai dengan kriteria inklusi dan ekslusi yang ditetapkan. Sampel pada kelompok kasus adalah orang yang tinggal di Desa Manjung Kecamatan Ngawen Kabupaten Klaten yang mengalami gangguan penernaan dan iritasi kulit di tahun 2018. Kelompok kontrol adalah orang yang tinggal di sekitar orang yang menderita gangguan pencernaan dan iritasi kulit serta memenuhi kriteria inklusi dan ekslusi yang ditetapkan. Teknik pengambilan sampel yang digunakan adalah purposive sampling. Jumlah sampel sebanyak 38 responden yang terdiri dari 19 responden kelompok kasus dan 19 responden kelompok kontrol yang diperoleh dari rumus berikut:

$$
n=\frac{\left(Z_{\alpha} \sqrt{2 P Q}+Z_{\beta} \sqrt{P_{1} Q_{1}+P_{2} Q_{2}}\right)^{2}}{\left(P_{1}-P_{2}\right)^{2}}
$$

Data penelitian dinalisis secara deskriptif dan pengujian hipotesis dilakukan dengan uji Chi-square. Pengumpulan data penelitian dilakukan dengan wawancara menggunakan kuesioner; pengukuran kondisi fisik sumur dengan menggunakan meteran dan lembar ceklist sesuai dengan SNI 03-2916-1992; dan pengambilan sampel air menggunakan jerigen serta botol winkler yang diberi perlakuan pengawetan dengan penambahan $\mathrm{MnSO}_{4} 1 \mathrm{ml}$ dan $\mathrm{NaOH}+\mathrm{KI} 1$ $\mathrm{ml}$ kemudian dihomogenkan untuk dilakukan pengujian di laboratorium sesuai dengan SNI 066989.14-2004.

\section{HASIL DAN PEMBAHASAN}

Data pada tabel 1, menunjukkan bahwa kondisi dinding sumur berhubungan dengan kejadian 
gangguan pencernaan dan iritasi kulit yang dibuktikan dari nilai $p$-value $=0,032(\mathrm{OR}=7,650 ; \mathrm{CI} 95 \%$ (1,370-42,713)). Responden yang memiliki sumur gali dengan kondisi dinding sumur yang tidak memenuhi syarat memiliki risiko 7,650 kali lebih besar terserang penyakit gangguan pencernaan dan iritasi kulit dibandingkan dengan responden yang memiliki sumur gali dengan kondisi dinding sumur yang memenuhi syarat. Menurut SNI 03-29161992 dinding sumur memenuhi syarat dikatakan baik jika diplester dan memiliki kedalaman $\geq 3 \mathrm{~m}$, dan tidak baik jika $<3 \mathrm{~m}$. Kondisi ini bertujuan untuk mengantisipasi adanya cemaran dari sumber lain, seperti teori menurut WHO tahun 2014 mengenai contoh bahaya atau situasi yang membahayakan berpotensi dan berkaitan dengan berbagai sumber air tidak berpipa adalah masuknya kontaminan karena kontruksi yang burukatau karena rusaknya dinding sumur. $^{8}$

Kondisi bibir sumur tidak berhubungan dengan kejadian gangguan pencernaan dan iritasi kulit yang dibuktikan dari nilai $p$-value $=0,065(\mathrm{OR}=6,182 ; \mathrm{CI}$ $95 \%(1,101-34,700)$ ). Hasil penelitian yang dilakukan di lapangan sebagian besar bibir sumur tidak memenuhi syarat, yaitu sebanyak 28 sumur gali dari total 38 sampel sumur gali tidak memenuhi syarat bibir sumur yang baik. Bibir sumur responden sebagian besar dibuat tidak berdasarkan standar yang telah ditentukan karena banyak ditemukan bibir sumur yang memiliki ketinggian $<0,8 \mathrm{~m}$ dan tidak diplester hanya dibuat dari batu bata yang ditumpuk dan ditambahkan semen. Kondisi bibir sumur yang ada di Desa Manjung sebesar 73,68\% tidak memenuhi syarat namun bukan menjadi penyebab terjadinya gangguan pencernaan dan iritasi kulit karena bibir sumur lebih berfungsi dalam aspek keselamatan, dan mencegah pencemaran atau pengotoran dari air permukaan apabila daerah tersebut adalah daerah banjir. Bibir sumur merupakan tembok yang kedap air yang berada diatas tanah berfungsi untuk mencegah kotoran dari air permukaan dan untuk menjamin aspek keselamatan. ${ }^{9}$ Sumber cemaran dari limbah soun tidak menjadi genangan-genangan di atas permukaan tanah, melainkan meresap ke permukaan tanah sehingga tidak terdapat kejadian masuknya genangan limbah soun ke dalam sumur akibat bibir sumur yang tidak memenuhi syarat. Hal tersebut menunjukkan bahwa tidak ada hubungan antara bibir sumur dengan kejadian gangguan pencernaan dan iritasi kulit yang terjadi pada wilayah tersebut.

Kondisi lantai sumur berhubungan dengan kejadian gangguan pencernaan dan iritasi kulit yang dibuktikan dari nilai $p$-value $=0,040(\mathrm{OR}=5,926$; $\mathrm{CI}$ $95 \%$ (1,287-27,283)). Responden yang memiliki sumur gali dengan kondisi lantai sumur yang tidak memenuhi syarat memiliki risiko 5,926 kali lebih besar terserang penyakit gangguan pencernaan dan iritasi kulit dibandingkan dengan responden yang memiliki sumur gali dengan kondisi lantai sumur yang memenuhi syarat. Hasil penelitian dilapangan diketahui bahwa lantai sumur yang dimiliki responden terbuat dari batu bata yang diplester dengan semen, namun lantai sumur masih banyak yang kurang dari $20 \mathrm{~cm}$ ketinggiannya dari permukaan tanah, selain itu kondisi lantai sumur sudah banyak yang mengalami keretakan dikarenakan faktor usia sumur yang sudah tua. Hasil ini relevan dengan pernyataan dari WHO tahun 2004 tentang terjadinya retakan atau patahan pada lantai sumur gali memungkinkan masuknya kontaminasi dengan cepat. ${ }^{8}$

Tabel 1.Hasil analisa statistik hubungan variabel bebas dengan kejadian gangguan pencernaan dan iritasi kulit di Desa Manjung Kecamatan Ngawen Kabupaten Klaten tahun 2018

\begin{tabular}{|c|c|c|c|c|c|c|c|}
\hline \multirow{2}{*}{ No } & \multirow{2}{*}{ Variabel } & \multirow{2}{*}{$\begin{array}{l}\text { Kasus } \\
\mathrm{n}=19\end{array}$} & \multirow{2}{*}{$\begin{array}{c}\text { Kontrol } \\
\mathrm{n}=19\end{array}$} & \multirow{2}{*}{$p$-value } & \multirow{2}{*}{ OR } & \multicolumn{2}{|c|}{$95 \% \mathrm{CI}$} \\
\hline & & & & & & Lower & Upper \\
\hline \multirow[t]{3}{*}{1.} & Kondisi dinding sumur & & & & & & \\
\hline & Memenuhi syarat & $2(10,5 \%)$ & $9(47,4 \%)$ & $0,032 *$ & 7,650 & 1,370 & 42,713 \\
\hline & Tidak memenuhi syarat & $17(89,5 \%)$ & $10(56,2 \%)$ & & & & \\
\hline \multirow[t]{3}{*}{2.} & Kondisi bibir sumur & & & & & & \\
\hline & Memenuhi syarat & $2(10,5 \%)$ & $8(42,1 \%)$ & 0,065 & 6,182 & 1,101 & 34,700 \\
\hline & Tidak memenuhi syarat & $17(89,5 \%)$ & $11(57,9 \%)$ & & & & \\
\hline \multirow[t]{3}{*}{3.} & Kondisi lantai sumur & & & & & & \\
\hline & Memenuhi syarat & $9(47,4 \%)$ & $16(84,2 \%)$ & $0,040^{*}$ & 5,926 & 1,287 & 27,283 \\
\hline & Tidak memenuhi syarat & $10(52,6 \%)$ & $3(15,8 \%)$ & & & & \\
\hline \multirow[t]{3}{*}{4.} & Kadar BOD & & & & & & \\
\hline & Memenuhi syarat & $14(73,7 \%)$ & $19(100 \%)$ & $0,046^{*}$ & 14,793 & - & - \\
\hline & Tidak memenuhi syarat & $5(26,3 \%)$ & $0(0 \%)$ & & & & \\
\hline
\end{tabular}

Ket : * (signifikan)

Sampel air sumur gali yang diuji kandungan BOD dalam penelitian ini sebanyak 38 sampel air sumur, dari 38 sampel kasus dan kontrol sebanyak 5 atau sebesar $13,15 \%$ sampel air sumur tidak memenuhi syarat baku mutu kriteria mutu air kelasI berdasarkan Peraturan Pemerintah Nomor 82. Tahun 
2001. Hasil analisis statistik menunjukkanhubungan antara kadar BOD dalam sampel air sumur dengan kejadian gangguan pencernaan dan iritasi kulit memiliki nilai $p$-value sebesar 0,046 yang berarti kadar BOD dalam sampel air sumur memiliki hubungan yang bermakna dengan kejadian gangguan pencernaan dan iritasi kulit yang terjadi, serta memiliki tingkat risiko hampir 15 kali lebih besar terserang penyakit gangguan pencernaan dan iritasi kulit daripada responden yang memiliki sumur gali dengan kadar BOD dalam air sumur yang memenuhi syarat.

BOD merupakan karakterisitik yang menunjukkan adanya jumlah oksigen terlarut yang diperlukan oleh mikroorganisme (biasanya bakteri) yang digunakan untuk mendekomposisi atau mengurai bahan organik dalam kondisi aerobik ${ }^{10,11}$. Kadar BOD yang tinggi dalam air biasanya ditandai dengan kandungan mikroorganisme yang tinggi. Mikroorganisme yang biasanya terkandung di dalamnya seperti bakteri kelompok Coliform, Escherichia coli, dan Streptococcus faecalis ${ }^{12}$. E. Coli jika masuk kedalam saluran pencernaan dalam jumlah yang banyak dapat membahayakan kesehatan, seperti mengalami gangguan pencernaan yaitu diare. Infeksi bakteri jenis Streptococcus dan Staphylococcus sering kali masuk ke pori-pori kulit

\section{DAFTAR PUSTAKA}

1. Suriawiria, U. Mikrobiologi Air dan DasarDasar Pengolahan Buangan Secara Biologis. Bandung : Penerbit Alumni. 2008.

2. Salim, H. Beban Pencemaran Limbah Domestik Dan Pertanian di Das Citarum Hulu. Jurnal Teknologi Lingkungan, Vol. 3, No. 2, Mei : 107-111. 2002.

3. Widiyanto, A. F., Yuniarno,S. dan Kuswanto. Polusi Air Tanah Akibat Limbah Industri dan LimbahRumah Tangga. Jurnal Kesehatan Masyarakat KEMAS 10 (2) 246-254. ISSN 1858-1196. 2015.

4. Sudarmadji. Perubahan Kualitas Airtanah di Sekitar Sumber Pencemar Akibat Bencana Gempa Bumi. Forum Geografi, 20(2):99-11. 2006.

5. Wardhana, W. A. 1994. Dampak Pencemaran Lingkungan. Yogyakarta:Penerbit Andi. 1994.

6. Dewi, Andita Y.P., dan Setyawan Purnama. Kajian Pengaruh Limbah Industri Soun Terhadap Kualitas Airtanah di Desa Manjung Kecamatan Ngawen Kabupaten Klaten.

7. Data 20 besar penyakit di Puskesmas Ngawen tahun 2018.

8. WHO tahun 2014 tentang kontruksi sumur gali.

9. Joko, T. Unit Air Baku Dalam Sistem Penyediaan Air Minum. Yogyakarta : Graha Ilmu. Cetakan Pertama, 2010.

10. Umaly, R. C. dan Ma L. A. Cuvin. Limnology: Laboratory and field guide, Physico-chemical pada lapisan kulit terluar (epidermis) hal tersebut menyebabkan kejadian iritasi kulit akibat kontak langsung dengan air yang tercemar.

\section{SIMPULAN}

Uji kandungan BOD pada sumur gali bertujuan untuk mengetahui kadar BOD yang terkandung didalam air sumur gali tersebut bersumber dari limbah cair industri soun atau dari faktor cemaran lain seperti selokan dan septictank.Sampel air sumur gali yang diuji kandungan BOD dalam penelitian ini sebanyak 38 sampel air sumur, dari 38 sampel kasus dan kontrol sebanyak 5 sampel air sumur tidak memenuhi syarat baku mutu kriteria mutu air kelas I berdasarkan Peraturan Pemerintah Nomor 82 Tahun 2001. Kondisi dinding sumur khususnya dinding dan lantai sumur sangat berpengaruh tehadap resapan dari limbah cair yang dihasilkan. Selain itu jarak dengan industri terdekat juga sangat berpengaruh tehadap kualitas air, sehingga terdapat 5 sampel air sumur yang melebihi baku mutu air badan air kelas I, 16 sampel air sumur yang bernilai $\geq 1 \mathrm{mg} / \mathrm{L}$, dan sisanya sebesar 17 sampel air sumur memiliki kandungan BOD namun masih $<1 \mathrm{mg} / \mathrm{L}$.

factors, Biological factors. National Book Store, Inc. Publishers. Metro Manila. 322 p. 1988.

11. Metcalf dan Eddy, INC. Wastewater Engineering : Treatment, Disposal, Reuse. $3^{\text {rd }}$ ed. (Revised by : G. Tchobanoglous and F. L. Burton). McGraw-Hill, Inc. New York, Singapore. 1334 p. 1991.

12. Schaecher, M. Escherichia coli. General Biology. Enscyclopedia of Microbiology, Vol. II, Academic press, Great Britain. 1992. 